\title{
KEBIJ AKAN MEDIASI PENAL TERHADAP PENYELESAIAN KONFLIK SARA DI KEPULAUAN KEI DALAM UPAYA PEMBAHARUAN HUKUM PIDANA NASIONAL
}

\author{
Rudini Hasyim Rado*, Barda Nawawi Arief**, Eko Soponyono*** \\ Program Studi Magister IImu Hukum \\ Fakultas Hukum Universitas Diponegoro \\ eko.soponyono@gmail.com
}

\begin{abstract}
ABSTRAK
Mediasi penal merupakan salah satu ciri khas hukum adat. Penyelesaian damai kasus pidana bahkan sudah merupakan kearifan lokal di berbagai daerah dan hukum adat di Indonesia yang bertujuan untuk menyelesaikan konflik, memulihkan keseimbangan dan mendatangkan rasa damai. Tujuan penelitian ini untuk mengetahui kebijakan penerapan mediasi penal terhadap penyelesaian konflik SARA berdasarkan hukum adat di Kepulauan Kei dan menganalisis kebijakan mediasi penal dalam upaya pembaharuan hukum pidana.

Metode penelitian yang digunakan dalam penelitian ini adalah penelitian kualitatif dengan pendekatan yuridis empiris dan yuridis normatif yang diorientasikan pada pendekatan nilai (value-oriented approach) dan pendekatan kebijakan (policy-oriented approach). Hasil penelitian menunjukkan bahwa kebijakan penerapan mediasi penal dalam penyelesaian konflik SARA Kei, bentuk penyelesaiannya di luar proses peradilan pidana melalui mekanisme Sdov (perundingan/musyawarah), yaitu perundingan yang dilakukan oleh para pihak dalam komunitas masing-masing selanjutnya dimintakan perdamaian pada struktur adat sebagai vhis bad (penengah) untuk mengakhiri konflik. Sedangkan kebijakan mediasi penal dalam pembaharuan hukum pidana dapat ditempuh melalui dua bentuk, yaitu bentuk mediasi penal di luar proses peradilan pidana (lembaga adat desa/lembaga kemasyarakatan desa) menggunakan mekanisme perundingan/musyawarah unsur mediator yaitu struktur adat/struktur desa dan bentuk mediasi penal sebagai bagian dari proses sistem peradilan pidana (SPP) melalui penyidik, penuntut umum, hakim, lembaga pemasyarakatan sebagai mediator pada tahapan masing-masing.
\end{abstract}

Kata Kunci: Konflik SARA; Mediasi Penal; Pembaharuan Hukum Pidana

* Mahasiswa Program Studi Magister IImu Hukum UNDIP

** Penulis Kedua, Penulis Koresponden

*** Penulis Ketiga 


\section{A. Pendahuluan}

\section{Latar Belakang}

Di mana ada masyarakat maka di situ ada peradilan, atau setidak-tidaknya di mana ada masyarakat di situ ada mekanisme penyelesaian perkara. Maka tidaklah mengherankan ketika Hilman Hadikusuma, menyatakan bahwa peradilan adat di Indonesia sudah ada sejak dahulu kala, jauh sebelum masa kejayaan kerajaankerajaan Hindu-Buddha di Indonesia. ${ }^{1}$

Mediasi penal merupakan penyelesaian perkara di luar pengadilan, di Indonesia penyelesaian perkara di luar pengadilan atau Alternative Dispute Resolution (ADR) "kesannya hanya" dikenal dalam ranah perdata, ${ }^{2}$ sedangkan untuk ranah pidana penyelesaian ditempuh dengan jalan diproses melalui pengadilan.

Barda Nawawi Arief, mengungkapkan bahwa walaupun pada umumnya penyelesaian sengketa di luar pengadilan hanya ada dalam sengketa perdata, namun dalam praktik sering juga kasus pidana diselesaikan di luar pengadilan melalui berbagai diskresi aparat penegak hukum atau melalui mekanisme musyawarah/perdamaian atau lembaga permaafan yang ada di dalam masyarakat (musyawarah keluarga; musyawarah desa; musyawarah adat). Praktik penyelesaian perkara pidana di luar pengadilan selama ini tidak ada landasan hukum formalnya, sehingga sering terjadi suatu kasus secara informal telah ada penyelesaian damai (walaupun melalui mekanisme

${ }^{1}$ Hedar Laudjeng, Mempertimbangkan Peradilan Adat, (Jakarta: HuMa, 2003), hlm. 3.

2Lihat lebih lanjut Undang-Undang No. 30 Tahun 1999 Tentang Abitrase dan Penyelesaian Sengketa. hukum adat), namun tetap saja diproses ke pengadilan sesuai hukum yang berlaku. ${ }^{3}$

Dengan keberadaan mediasi penal menurut hukum adat ini setidaknya memberikan harapan terhadap kebijakan hukum pidana mendatang akan lebih memberikan perhatian lebih terhadap nilainilai sosial yang tumbuh dan berkembang di dalam masyarakat. Kebijakan hukum pidana tentang gugurnya kewenangan penuntutan yang salah satunya diakibatkan oleh adanya penyelesaian di luar proses, akan memberikan ruang terhadap lembaga-lembaga yang terdapat di dalam masyarakat adat di Indonesia untuk dijadikan alternatif penyelesaian tindak pidana.

Walaupun penyelesaian tindak pidana melalui lembaga adat ini belum diatur secara positif, namun setidaknya dalam kebijakan di masa yang akan datang yaitu dalam pembaruan hukum pidana di Indonesia melalui pembahasan Rancangan KUHP (R-KUHP) proses penyelesaian di luar sistem peradilan pidana formal yang ada mulai dipertimbangkan. Dalam R-KUHP tahun 2015 pada Pasal 152 salah satunya mengatur "kewenangan penuntutan gugur jika: (d) telah ada penyelesaian di luar proses".

\section{Perumusan Masalah}

Berdasarkan latar belakang di atas, maka dapat dirumuskan permasalahannya sebagai berikut:

${ }^{3}$ Barda Nawawi Arief, Mediasi Penal Penyelesaian Perkara di Luar Pengadilan, (Semarang, Penerbit Pustaka Magister, 2010), hlm. 3-4. 
1. Bagaimana kebijakan penerapan mediasi penal terhadap penyelesaian konflik SARA di Kepulauan Kei saat ini?

2. Bagaimana kontribusi kebijakan mediasi penal dalam upaya pembaharuan hukum pidana di masa yang akan datang?

\section{Metode Penelitian}

Metode penelitian yang digunakan dalam penelitian ini adalah penelitian kualitatif dengan pendekatan yuridis empiris dan yuridis normatif yang diorientasikan pada pendekatan nilai (valueoriented approach) dan pendekatan kebijakan (policy-oriented approach). Data yang digunakan dalam penelitian adalah data primer yang didapat dari wawancara dan data sekunder dari berbagai literatur.

\section{Kerangka Teoritik}

Ubi societas ibi ius (di mana ada masyarakat di situ ada hukum). Hal itu diungkapkan oleh Cicero, seorang filsuf yang sangat terkenal, hidup lebih dari 2000 tahun yang lalu. ${ }^{4}$

Von Savigny dari aliran sejarah dan kebudayaan, bahwa hubungan hukum dan masyarakat itu demikian erat sehingga tidak dapat dipisahkan, karena hukum menurutnya adalah pencerminan jiwa rakyat. Menurut Puchta, semua hukum adalah perwujudan dari kesadaran yang umum ini. Dikatakannya: ${ }^{5}$

Hukum itu tumbuh bersama-sama dengan pertumbuhan, dan menjadi kuat bersama-sama dengan kekuatan dari rakyat, dan pada

${ }^{4}$ Hedar Laudjeng, Mempertimbangkan Peradilan Adat, Op. Cit., hlm. 3.

${ }^{5}$ Satjipto Rahardjo, IImu Hukum, (Bandung: PT. Citra Aditya Bakti, 2014), hlm. 316. akhirnya ia mati manakala bangsa itu kehilangan kebangsaannya.

Herowati Poesoko dan Dominikus Rato mengemukakan berkaitan dengan Volksgeist, maka selama ada masyarakat di situ pula tentunya ada penyelesaian perkara yang memberikan nilai keadilan dan kemanfaatan bagi para pihak yang berperkara. Oleh karena itu seyogyianya penyelesaian perkara secara musyawarah ${ }^{6}$ sebagai jiwa bangsa Indonesia. Tentunya perkara-perkara tersebut membutuhkan penyelesaian yang sederhana, biaya murah dan cepat serta tuntas. ${ }^{7}$

Martin Wright mengatakan mediasi, merupakan suatu proses di mana korban dan pelaku kejahatan saling bertemu dan berkomunikasi, serta dengan bantuan pihak ketiga, langsung atau tidak, memudahkan korban untuk mengekspresikan apa yang menjadi kebutuhan dan perasaannya, dan memungkinkan pelaku

6Sila keempat mengajarkan kepada kita untuk menentukan sebuah pilihan melalui cara musyawarah. Mengutamakan musyawarah dalam mengambil putusan untuk kepentingan bersama. Musyawarah untuk mencapai mufakat diliputi semangat kekeluargaan, sehingga kalau di breakdown falsafah "musyawarah" mengandung 5 (lima) prinsip sebagai berikut: pertama, conferencing (bertemu untuk saling mendengar dan mengungkapkan keinginan); kedua, search solutions (mencari solusi atau titik temu atas masalah yang sedang dihadapi); ketiga, reconciliation (berdamai dengan tanggungjawab masing-masing); keempat, repair (memperbaiki atas semua akibat yang timbul); dan kelima, circles (saling menunjang). Musyawarah/perwakilan dilaksanakan atas dasar kebijaksanaaan. Lihat dalam Kuat Puji Prayitno, Restorative Justice Untuk Peradilan di Indonesia (Perspektif Yuridis Filosofis dalam Penegakan Hukum In Concreto), Jurnal Dinamika Hukum, (Purwokerto: FH Unsoed, 2012), hlm. 414.

${ }^{7}$ Herowati Poesoko, et al., Eksistensi Pengadilan Adat dalam Sistem Peradilan di Indonesia, (Surabaya: Laksbang Justitia, 2014), hlm. 67. 
Jurnal Law Reform

Volume 12, Nomor 2, Tahun 2016

menerima dan bertanggung jawab atas perbuatannya. $^{8}$

Penelitian ini dimulai dari ide pembaharuan hukum pidana di mana upaya pembaharuan hukum pidana dalam rangka menciptakan sistem hukum pidana nasional yang sudah diamanatkan sejak fajar kemerdekaan bangsa Indonesia di tahun 1945 sampai sekarang. Namun apa yang telah dikerjakan itu sama sekali tidak bisa dikatakan suatu law reform secara total seperti yang dimaksud oleh Gustav Radbruch.

Khususnya di bidang pembaharuan hukum pidana, J erome Hall pernah menyatakan: 9

Perbaikan/pembaharuan atau pengembangan hukum pidana harus merupakan suatu usaha permanen yang terus menerus dan berbagai catatan/dokumen rinci mengenai hal itu seharusnya disimpan dan dipelihara.

Dalam hal pembaharuan kebijakan hukum pidana berkaitan dengan mediasi penal Barda Nawawi Arief, dalam bukunya melukiskan bahwa: ${ }^{10}$

Adapun latar belakang pemikirannya ada yang dikaitkan dengan ide-ide pembaharuan hukum pidana (penal reform), dan ada yang dikaitkan dengan masalah pragmatisme. Ide-ide "penal reform" itu antara lain ide perlindungan korban,

8Martin Wright dalam Trisno Raharjo, Mediasi Pidana dalam Sistem Peradilan Pidana Suatu Kajian Perbandingan dan Peranannya di Indonesia, (Yogyakarta: Buku Litera dan Lab. Hukum FH UMY, 2011), hlm. 15.

${ }^{9}$ Jerome Hall dalam Barda Nawawi Arief, Beberapa Aspek Pengembangan IImu Hukum Pidana (Menyongsong Generasi Hukum Pidana Indonesia), Pidato Pengukuhan Guru Besar, (Semarang: Badan Penerbit Undip, 2011), hlm. 28-29. 21-22.

Barda Nawawi Arief, Mediasi Penal..., Op. Cit., hlm.
Program Studi Magister Ilmu Hukum

Fakultas Hukum Universitas Diponegoro

ide harmonisasi, ide restorative justice, ide mengatasi kekakuan/formalitas dalam sistem yang berlaku, ide menghindari efek negatif dari sistem peradilan pidana dan sistem pemidanaan yang ada saat ini, khususnya dalam mencari alternatif lain dari pidana penjara (alternative to imprisonment/alternative to custody) dan sebagainya. Latar belakang pragmatisme antara lain untuk mengurangi stagnasi atau penumpukan perkara ("the problems of court case overload"), untuk penyederhanaan proses peradilan dan sebagainya.

Berbicara masalah mediasi penal dalam kaitannya dengan pembaharuan hukum pidana, maka perlu dipikirkan menghidupkan/menguatkan kembali peradilan adat sebagai kearifan lokal dalam hukum adat di Indonesia yang berlandaskan alam pikiran kosmis, magis dan religius.

\section{B. HASIL PENELITIAN DAN PEMBAHASAN}

1. Kebijakan Penerapan Mediasi Penal Terhadap Penyelesaian Konflik SARA di Kepulauan Kei Saat Ini

Dalam masyarakat, mediasi bukanlah suatu hal yang baru. Ketidakbaruan mediasi dibuktikan dengan adanya musyawarah. Disampaikan oleh Marc Levin, pendekatan yang dulu dinyatakan usang, kuno dan tradisional dikatakan sebagai pendekatan yang progresif. ${ }^{11}$

${ }^{11}$ Marc Levin dalam Eva Achjani Zulfa, Pergeseran Paradigma Pemidanaan, (Bandung: Lubuk Agung, 2011), hlm. 67. 
Budaya Indonesia yang penuh kompromi dan kooperatif muncul di mana saja dalam berbagai lapisan masyarakat. Perlu disadari bahwa secara kultural masyarakat Indonesia sangat menjunjung tinggi pendekatan konsensus. Menurut Muladi, dialog antara yang berselisih untuk menyelesaikan masalahnya adalah langkah yang sangat positif. Dengan konsep ini muncul istilah ADR yang dalam hal-hal tertentu lebih memenuhi tuntutan keadilan dan efesien. ADR ini merupakan bagian dari konsep restorative justice ${ }^{12}$ yang menempatkan peradilan pada posisi mediator. ${ }^{13}$

Mediator dalam konteks hukum nasional pada umumnya adalah sarjana-sarjana hukum yang sudah mendapatkan pelatihan/pendidikan tertentu, sedangkan dalam hukum adat posisi mediator diisi oleh struktur adat seperti raja, tua-tua adat maupun tokoh masyarakat. Von Savigny, mengungkapkan bahwa walaupun hukum untuk sebagian merupakan milik para sarjana hukum, namun sebagian lain masih tetap hukum rakyat. ${ }^{14}$ Hukum ini disebut hukum yang hidup (hukum adat) yang dikendalikan struktur adat untuk dibangun kembali dari keadaan yang kacau ini.

Penelusuran sejarah lokal masyarakat Kei tidak pernah sepi dari konflik, bahkan di masa lampau

${ }^{12}$ Restorative justice merupakan sebuah istilah baru terhadap konsep lama. Pendekatan restorative justice telah digunakan dalam memecahkan masalah konflik antara para pihak dan memulihkan perdamaian di masyarakat. Lihat Dokumen United Nations Office for Drug Control and Crime Prevention, Handbook on Justice for Victim, Centre for Internasional Crime Prevention, New York, 1999, hlm. 42.

13Muladi dalam Sahuri Lasmadi, Mediasi Penal dalam Sistem Peradilan Pidana Indonesia, Jurnal Hukum (tanpa penerbit, tanpa tahun), hlm. 2.

${ }^{14}$ Von Savigny dalam Hedar Laudjeng, Mempertimbangkan Peradilan Adat, 0p. Cit., hlm. 11. pernah terjadi perang antar wilayah adat sesuai dengan pandangan dasar dan hukum yang telah diuraikan sebelumnya. Tetapi, sejarah panjang konflik atau perang tersebut pada akhirnya dapat diselesaikan dengan mengutamakan adanya musyawarah, perdamaian dan saling memaafkan serta tidak tergopoh-gopoh begitu saja menyerahkannya ke peradilan negara. ${ }^{15}$

Di kepulauan Kei, setiap konflik yang bersifat kriminal atau tindak pidana lainnya merupakan pelanggaran adat, maka peranan pemimpin/pemangku adat yang bertanggung jawab terhadap proses penyelesaiannya yang menurut Friedman sebagai struktur hukum. Menurut V. A.

Rahail, mengungkapkan sebagai berikut: ${ }^{16}$

Raja harus melekat dan tidak dapat dipisahkan dengan rakyatnya. Uud entauk na atvunad (kepala bertumpu pada bahu). ${ }^{17}$ Di setiap "kepala" manusia terdapat otak, mata, telinga, hidung dan mulut yang melaksanakan fungsinya masing-masing. Hati dan jantung ada pada bagian badan manusia. Artinya seorang pemimpin (kepala) dalam masyarakat adat Kei dalam melaksanakan fungsinya harus mendengar, melihat, melindungi dan memahami hati nurani rakyatnya, berbicara sesuai dengan kemauan rakyatnya, karena suara yang keluar saat berbicara didorong oleh nafas dari dada atau perut. Kesemuanya ini

15Hilman Hadikusuma, Pengantar IImu Hukum Adat Indonesia, (Bandung: Mandar Maju, 2003), hlm. 38.

${ }^{16}$ Wawancara V. A. Rahail, Raja Ratshap Maur Ohoiwut, tanggal 17 Februari 2016.

17Pasal 1 Hukum Adat Kei Larwul Ngabal. 
sulit dilakukan oleh orang yang tidak memahami hukum adat Kei.

Beruntung bagi masyarakat Kei karena telah memiliki suatu kearifan lokal yang mumpuni dalam mengelola konflik SARA Kei. Penanganan konflik SARA tersebut oleh struktur adat (Rat, Orang Kai/Soa) selaku pemimpin adat sekaligus hakim perdamaian adat mirip dengan mediator yang menghendaki komunikasi lebih fleksibel, para pihak (perseorangan atau kelompok masyarakat) agar konflik lebih mudah diselesaikan. ${ }^{18}$

Kedudukan raja sebagai "penengah" konflik SARA Kei dalam upaya mendamaikan pihak bertikai dengan syarat menolak secara tegas adanya campur tangan aparat keamanan (polisi dan tentara), dalam prakarsa perdamaian yang direncanakan. Mereka bertekad akan melakukannya sendiri dengan "cara dan bahasa adat Kei". J . P. Rahail, mengungkapkan bahwa:19

Merekalah (baca: aparat pemerintah, peneliti) yang justru menjadi sebab konflik yang terjadi, jadi sama sekali aneh kalau mereka ingin menjadi penengah dan pendamai. Mereka boleh ikut membantu tetapi bukan sebagai pemrakarsa dan pameran utama langsung di dalamnya.

Penyelesaian perkara di kepulauan Kei lebih menenkankan pada kearifan lokal, pembicaraan, dan peribahasa terekam dalam mekanisme Sdov

18| Made Widnyana, Hukum Pidana Adat dalam Pembaharuan Hukum Pidana (Jakarta: Fikahati Aneska, 2013), hlm. 16-17.

19j. P. Rahail dalam P. M. Laksono dan Roem Topatimasang, (ed)., Ken Sa Faak, Benih-benih Perdamaian dari Kepulauan Kei, (Tual-Jogyakarta: Nen Mas II-Insist Press, 2004), hlm. 106. atau perundingan/musyawarah (yang merupakan nilai-nilai asli bangsa Indonesia) dan cara damai. Sdov berarti berkumpul duduk untuk berunding/bermusyawarah (dok Tasdov). Sdov (perundingan) dilakukan oleh para pihak dalam komunitas/kelompoknya masing-masing, hasil dari perundingan tersebut diajukan kepada struktur adat sebagai vhis bad (penengah) yang kemudian mengadakan musyawarah dengan mengundang atau mendatangi para pihak dalam komunitas tersebut untuk mengakhiri konflik. Para pihak yang dipertemukan, selanjutnya diadakan dialog-dialog berlandaskan falsafah "Ain ni ain" (kita adalah satu), dan "Manut ain mehe ni tilur, fuut ain mehe ni ngifun" (semua orang Kei berasal dari satu keturunan), ${ }^{20}$ disertai semangat fangnanan (kasih sayang), perasaan solidaritas ini memancarkan suasana kehidupan yang harmonis, rukun dan tenteram. Termasuk dalam penyelesaian konflik SARA Kei digunakan mekanisme Sdov (perundingan/musyawarah/mediasi).

Dapat dikemukakan bahwa Raja maupun struktur adat lainnya berperan sebagai pembantu Raja dalam menjalankan sistem pemerintahan di desa, baik menyangkut kestabilan masyarakat maupun kehidupan adat istiadat. Dan bila terjadi konflik, maka kewajiban dari para pemimpin adat untuk menyelesaikannya dengan melibatkan masyarakat yang bersengketa. Salah satu bentuk dalam penyelesaian konflik dengan menghadirkan pihak yang bermasalah dalah satu perundingan/musyawarah adat dengan

20Wawancara Abdul Hamid Rahayaan, Raja Ratshap Tabab Yamlim, tanggal 6 Februari 2016. 
mendudukkan persoalan yang menjadi "delik adat/desa, karena memiliki kelebihan yang tidak aduan" pihak yang berperkara kemudian struktur hukum yang dipimpin oleh raja mendamaikan pihak ditemukan dalam sistem peradilan pidana. yang bermasalah yang dideklarasikan dalam suatu upacara adat dalam bentuk pelanggaran dan sanksi untuk tidak mengulangi perseteruan. Bentuk pelarangan adalah dengan menanamkan sasi (hawear), sebagai larangan memulai konflik.

Menurut Muladi, penyelesaian secara perdamaian memiliki nilai sama dengan putusan hakim. Jika kita melihat ketentuan hukum perdata khususnya Pasal 1338 KUHPerdata, "Semua kesepakatan yang dibuat sesuai dengan undangundang bagi para pihak yang membuatnya". ${ }^{21}$

Dapat dikemukakan bahwa masyarakat Kei, telah memiliki kearifan lokal dalam menyelesaikan perkara, melalui mekanisime Sdov (perundingan) antara para pihak dalam kelompok masing-masing untuk memecahkan persoalan, selanjutnya perkara tersebut diajukan pada tingkatan struktur adat untuk selesaikan.

Telah dikemukakan bahwa peradilan pidana bukan merupakan institusi yang paling baik di dalam menyelesaikan suatu konflik. Penyelesaian melalui peradilan pidana juga akan merusak hubungan kekeluargaan, menganggu hubungan yang awalnya damai, tenteram, harmonis dan menjadi hancur. Atas dasar beberapa kelemahan tersebut, proses penyelesaian konflik tidak hanya berada di tangan peradilan pidana tapi dengan mengefektifkan eksistensi mediasi oleh struktur

21Muladi dalam Suparmin, Model Polisi Dari Prespektif Alternative Dispute Resolution (ADR) (Studi Penyelesaian Konflik antar Partai Politik), (Semarang: Badan Penebit Universitas Diponegoro, 2012), hlm. 40.

Pertama, mediasi akan mengurangi perasaan balas dendam korban, lebih fleksibel dan lebih sedikit menghabiskan biaya, serta prosesnya lebih cepat dibandingkan dengan proses litigasi.

Kedua, beban sistem peradilan pidana karena menumpuknya perkara dan proses penyelesaianya memakan waktu yang tidak sedikit banyak dapat dikurangi dengan kehadiran mediasi antara pelaku dan korban. Ketiga, mediasi memberikan kesempatan kepada korban bertemu dengan pelaku untuk membahas kejahatan yang telah merugikan kehidupannya, mengungkapkan perhatian dan perasaannya serta meminta adanya restitusi. Keempat, mediasi menciptakan kembali hubungan yang harmonis antara korban dan pelaku. Kondisi ini tidak ditemukan di dalam penyelesaian konflik melalui sistem peradilan pidana. Pemberian maaf korban kepada pelaku akan mengurangi rasa bersalah pelaku dan menciptakan rekonsiliasi antara keduanya.

\section{Kebijakan Mediasi Penal dalam Upaya Pembaharuan Hukum Pidana di Masa Yang Akan Datang}

Akhirnya, keberadaan R-KUHP 2015 ini setidaknya memberikan harapan terhadap kebijakan hukum pidana mendatang akan memberikan perhatian lebih terhadap nilai-nilai sosial yang tumbuh dan berkembang di dalam masyarakat. Kebijakan hukum pidana tentang gugurnya kewenangan penuntutan yang salah satunya diakibatkan oleh telah ada penyelesaian di 
luar proses atau penyelesaian damai (mediasi penal), bentuk penyelesaian ini sebagaimana masyarakat Kei dalam menyelesaikan konflik SARA melalui Sdov (perundingan) antara para pihak (kelompok) masing-masing pada komunitasnya selanjutnya diserahkan kepada struktur adat Kei sebagai vhis bad (penengah) kemudian mengadakan musyawarah dengan mengundang atau mendatangi langsung para pihak dalam komunitasnya tersebut guna dipertemukan dan didamaikan untuk mengakhiri konflik. Dengan diakui penyelesaian di luar proses ini, tentu akan memberikan ruang terhadap lembaga-lembaga masyarakat adat lainnya/lembaga kemasyarakatan desa/sosial lainnya di Indonesia untuk dijadikan alternatif penyelesaian perkara/konflik.

\section{Pasal 152}

Kewenangan penuntutan gugur, jika:

a. telah ada putusan yang memperoleh kekuatan hukum tetap;

b. terdakwa meninggal dunia;

c. daluwarsa;

d. telah ada penyelesaian di luar proses;

e. ...

f. $\quad \ldots$

g. $\ldots$

h. $\ldots$

i. $\ldots$

j. $\quad \ldots$

(cetak tebal, peneliti).

Penyelesaian di luar pengadilan melalui mekanisme adat atas tindak pidana adat diselesaikan/dimediasi oleh struktur adat seperti Raja, Kepala Desa, Tokoh Masyarakat dan sebagainya dengan mempertemukan dan mendamaikan para pihak yang terlibat perselisihan. Dalam mediasi tersebut dikedepankan proses dialog, para pihak didorong untuk saling maafmemaafkan, menghilangkan rasa denda dan mencari solusi yang menguntungkan (win-win solution). Dengan adanya bentuk penyelesaian perkara di luar pengadilan ini, diharapkan dapat memberikan keadilan hukum, kemanfaatan hukum dan kepastian hukum bagi pihak yang berperkara. Dengan demikian, mediasi penal ini menjadi dasar agar perkara tersebut sebagai dasar penghapus penuntutan atau pemidanaan.

Terhadap pelanggaran tindak pidana, penyelesaian damai (mediasi penal), dapat dijadikan bahan kontribusi dalam pembaharuan hukum pidana, melalui dua bentuk atau cara, sebagai berikut:

1. Mediasi penal di luar proses peradilan pidana, antara lain melalui lembaga desa adat/lembaga kemasyarakatan desa. Di sini diperlukan landasan hukum berupa kebijakan atau aturan hukum yang menetapkan tentang:

a. Tindak pidana yang dapat dimediasikan di luar proses peradilan pidana;

b. Mediasi penal yang dilakukan oleh pihak pelaku dan korban di luar pengadilan terhadap tindak pidana tertentu diakui keabsahannya jika dilakukan secara suka rela; 
Jurnal Law Reform

Volume 12, Nomor 2, Tahun 2016

c. Mediasi penal difasilitasi oleh mediator (di antaranya oleh struktur adat/desa);

d. Kekuatan hukum hasil kesepakatan yang dicapai oleh pihak pelaku dan korban, sebagai keputusan yang sah dan final sehingga tidak dapat diganggu gugat dan tidak perlu dikuatkan melalui penetapan pengadilan cukup apabila disahkan dengan materai dan tanda tangan semua pihak. Hal ini mengingat bahwa pelaksanaan mediasi penal adalah bersifat suka rela;

e. Hasil kesepakatan yang dicapai dalam mediasi penal sebagai alasan hapusnya penuntutan tindak pidana yang telah dimediasikan.

2. Mediasi penal sebagai bagian proses sistem peradilan pidana (SPP), sebagai berikut:

a. Mediasi penal pada tahap penyidikan tindak pidana, tahap penyidikan adalah tahap awal dari proses peradilan pidana. Pada tahap ini dimungkinkan bagi penyidik untuk meneruskan atau tidak meneruskan tindak pidana ke dalam proses peradilan pidana. Mediasi pada tahap penyidikan ini merupakan kombinasi model mediasi informal mediation, victim-offender mediation dan reparation negotiation programmes.

b. Mediasi penal pada tahap penuntutan, setelah pelimpahan dari penyidik ke penuntut umum. Dalam tahap ini penuntut umum tidak semestinya langsung meneruskan tindak pidana ke pengadilan
Program Studi Magister IImu Hukum Fakultas Hukum Universitas Diponegoro

melainkan mendorong para pihak untuk berdamai. kombinasi model mediasi informal mediation, victim-offender mediation dan reparation negotiation programmes. Atau penuntut umum dapat langsung menghentikan penuntutan bilamana telah ada penyelesaian di luar proses sistem peradilan pidana atau melalui penyelesaian lembaga adat/desa.

c. Mediasi penal pada tahap pemeriksaan sidang pengadilan, mediasi penal dilakukan pada tahap ini adalah setelah perkara dilimpahkan ke pengadilan oleh penuntut umum. Dalam mediasi tahap ini sebagaimana dalam perkara perdata, hakim menawarkan alternatif penyelesaian perkara pidana dengan cara perdamaian kepada para pihak, yaitu pihak pelaku tindak pidana dan pihak korban sebelum dilakukan proses pemeriksaan di depan sidang pengadilan dengan melihat kriteria tindak pidana yang dilakukan oleh terdakwa. Mediasi ini jika mencapai kesepakatan maka hasilnya dapat digunakan sebagai alasan untuk menghapuskan menjalankan pidana bagi pelaku tindak pidana. Mediator pada tahap ini bisa dilakukan oleh hakim ataupun mediator dari luar pengadilan. Mediasi ini adalah gabungan dari model victimoffender mediation dan reparation negotiation programmes. 
d. Mediasi penal pada tahap pelaku menjalankan sanksi pidana penjara, pada tahapan ini mediasi penal dilakukan baik berupa reparation negotiation programme yang menitiberatkan pada pembayaran kompensasi dari pelaku kepada korban, maupun berupa bentuk victim offendermediation, yang menitiberatkan baik pada konsep rekonsiliasi maupun pada kesepakatan pembayaran ganti kerugian kepada korban. Mediasi yang dilakukan pada tahap pelaku sedang menjalani pidananya khususnya pidana penjara, berfungsi sebagai alasan untuk menghapuskan kewenangan menjalankan sebagian pidana jika pelaku telah menjalankan sebagian pidananya.

\section{PENUTUP}

\section{Kesimpulan}

Pembahasan pada permasalahan yang disajikan dalam bagian hasil penelitian dan pembahasan menunjukkan beberapa kesimpulan sebagai berikut:

1. Kebijakan penerapan mediasi penal dalam penyelesaian konflik SARA Kei, bentuk penyelesaiannya di luar proses peradilan pidana melalui mekanisme Sdov (perundingan/ musyawarah), yaitu perundingan yang dilakukan oleh para pihak dalam komunitas/kelompoknya masing-masing, hasil perundingan tersebut diajukan kepada struktur adat sebagai vhis bad (penengah) yang kemudian mengadakan musyawarah dengan mengundang atau mendatangi para pihak dalam komunitas tersebut untuk mengakhiri konflik.

2. Kebijakan mediasi penal dalam pembaharuan hukum pidana dapat dikontribusikan melalui dua cara atau bentuk, yaitu bentuk mediasi penal di luar proses peradilan pidana (lembaga adat desa/lembaga kemasyarakatan desa) melalui mekanisme perundingan/ musyawarah, mediator terdiri dari unsur struktur adat/struktur desa dan bentuk mediasi penal sebagai bagian dari proses sistem peradilan pidana (SPP) dapat dimediasi dari tahap penyidikan oleh penyidik, penuntutan oleh penuntut umum, pengadilan oleh hakim atau pelaku menjalankan pidana penjara oleh lembaga pemasyarakatan.

\section{Saran}

Berdasarkan hasil penelitian dan pembahasan ini menyarankan:

1. Disarankan bahwa meskipun penyelesaian diproses di luar pengadilan melalui lembaga adat desa/lembaga kemasyarakatan desa setempat, namun bilamana diadakan/dijatuhi pidana/ sanksi terhadap pelaku, pidana tersebut merujuk pada pandanannya yang ada dalam KUHP.

2. Disarankan agar baik struktur adat/struktur desa maupun komponen penegak hukum penyidik, penuntut umum, hakim dan lembaga pemasyarakatan dapat bertindak sebagai mediator dalam penyelesaian tindak pidana 
terhadap bentuk mediasi penal di luar proses peradilan pidana maupun mediasi penal sebagai bagian dari sistem peradilan pidana.

\section{DAFTAR PUSTAKA}

\section{Buku}

Hadikusuma, Hilman, 2003, Pengantar IImu Hukum Adat Indonesia, Bandung: Mandar Maju.

Laksono, P. M., dan Topatimasang, Roem, (ed)., 2004, Ken Sa Faak, Benih-benih Perdamaian dari Kepulauan Kei, Tual-Jogyakarta: Nen Mas II-Insist Press.

Laudjeng, Hedar, 2003, Mempertimbangkan Peradilan Adat, Jakarta: HuMa.

Nawawi Arief, Barda, 2010, Mediasi Penal Penyelesaian Perkara di Luar Pengadilan, Semarang: Penerbit Pustaka Magister.

, 2011, Beberapa Aspek Pengembangan IImu

Hukum Pidana (Menyongsong Generasi Baru

Hukum Pidana Indonesia), Pidato Pengukuhan

Guru Besar, Semarang: Badan Penerbit Undip.

Poesoko, Herowati, et al., 2014, Eksistensi

Pengadilan Adat dalam Sistem Peradilan di

Indonesia, Surabaya: LaksBang Justitia.

Rahardjo, Satjipto, 2014, IImu Hukum, Bandung:

PT. Citra Aditya Bakti.

Raharjo, Trisno, 2011, Mediasi Pidana dalam

Sistem Peradilan Pidana Suatu Kajian

Perbandingan dan Peranannya di Indonesia, Yogyakarta: Buku Litera dan Lab. Hukum FH UMY.
Suparmin, 2012, Model Polisi Dari Prespektif Alternative Dispute Resolution (ADR) (Studi Penyelesaian Konflik antar Partai Politik), Semarang: Badan Penebit Universitas Diponegoro.

Widnyana, I Made, 2013, Hukum Pidana Adat dalam Pembaharuan Hukum Pidana, Jakarta: PT. Fikahati Aneska.

Zulfa, Eva Achjani, 2011, Pergeseran Paradigma Pemidanaan, Bandung: Lubuk Agung.

\section{Karya Ilmiah/J urnal}

Lasmadi, Sahuri, tanpa tahun, Mediasi Penal dalam Sistem Peradilan Pidana Indonesia, Jurnal Hukum, tanpa penerbit.

Prayitno, Kuat Puji, 2012, Restorative J ustice Untuk Peradilan di Indonesia (Perspektif Yuridis Filosofis dalam Penegakan Hukum In Concreto), Purwokerto: FH Unsoed.

United Nations Office For Drug Control and Crime Prevention, Handbook on J ustice for Victims, Centre for International Crime Prevention, New York, 1999.

\section{Peraturan Perundang-Undang}

Undang-Undang Nomor 30 Tahun 1999 Tentang Abitrase dan Penyelesaian Sengketa, Lembaran Negara Republik Indonesia Tahun 1999 Nomor 138, Tambahan Lembaran Negara Republik Indonesia Nomor 3872. 